\title{
The Use of English Songs with Social Content as a Situated Literacy Practice: Factors that Influence Student Participation in the EFL Classroom
}

\author{
La utilización de canciones en inglés con contenido \\ social como práctica situada: factores que \\ influyen en la participación de los estudiantes en \\ la clase de inglés como lengua extranjera
}

\author{
Nilsen Palacios Mena ${ }^{1}$ \\ Claudia Marcela Chapetón ${ }^{2}$
}

\section{Abstract}

This action research study examines the factors that influence student participation when songs with social content are utilised in the EFL classroom. The study proposes the use of English songs as a situated social practice under the perspective of critical pedagogy. The study was done in the 11th English class of a public high school located in the south of Bogota, Colombia. Data was collected through field observations, semistructured interviews, questionnaires and artefacts made by the students. The results indicate that factors relate to the songs and the students themselves. The study suggests that providing different opportunities for students to explore different dimensions of literacy that go beyond the linguistic aspects of a foreign language can encourage meaningful participation and interest in learning English as a Foreign Language.

Keywords

English as a Foreign Language, songs in the English class, literacy as situated social practice, classroom participation, critical pedagogy.

\section{Resumen}

Este estudio de investigación-acción examina los factores que influyen en la participación de los estudiantes en la clase de inglés como lengua extranjera cuando se hace uso de canciones con contenido social. El estudio propone el uso de canciones en inglés como práctica social situada desde la perspectiva de la pedagogía crítica. El estudio se desarrolló en un colegio público localizado al sur de Bogotá, Colombia, en la clase de inglés en secundaria. Los datos fueron recolectados a través de observaciones de campo, entrevistas semi-estructuradas, cuestionarios y artefactos producidos por los estudiantes. Los resultados indican que los factores se relacionan con las canciones y con los estudiantes mismos. El estudio sugiere que ofrecer oportunidades en las cuales los estudiantes exploran diferentes dimensiones de alfabetización que van más allá de los aspectos lingüísticos de la lengua extranjera, puede motivar una participación significativa e interés en el aprendizaje del inglés como lengua extranjera.

\section{Palabras clave:}

Inglés como lengua extranjera, canciones en la clase de inglés, alfabetización como práctica social situada, participación en clase, pedagogía crítica.

Artículo recibido el 9 de febrero de 2014 y aprobado el 20 de agosto de 2014

2 Universidad Pedagógica Nacional, Facultad de Humanidades, Departamento de Lenguas, Bogotá, Colombia. Correo electrónico: cchapeton@pedagogica.edu.co 


\section{Introduction}

In spite of the efforts made by the Colombian educative institutions to comply with the national education policies which argue for the need to reach certain proficiency levels in a second language (Ministerio de Educación Nacional, MEN, 2006), it seems that the learning of English in the classroom context at public high schools is still a great challenge. As Guevara and Ordoñez (2012) point out, it is particularly difficult to motivate our adolescents to learn the foreign language in a mostly monolingual sociolinguistic context where there is no real need or wish to use it for authentic communicative purposes.

From empiric observation in the EFL classroom at a public school in Bogotá, it appeared that a focus on grammatical structures and vocabulary learning was privileged with little concern for students' social realities and interests. This observation seemed to be connected to a teacher-centered practice that gave very little room for students' active participation, restricting their interaction and communication either in English or Spanish.

In view of exploring how these practices can be transformed to enhance students' interest and active participation in the foreign language learning process, this study looks into the impact that the use of songs with social content framed within a literacy as a situated social perspective may have in providing EFL learners with opportunities to find meaningful ways to use the language in classroom contexts by making connections with their own lives and social realities. Being music a topic that generally motivates students' participation, enhancing literacy as a situated social practice in these students through the use of activities based on selected songs, might become a useful classroom tool. This is due to two main reasons: The first one is the fact that music is very popular around the world and the second, that these EFL students show a great interest in music. English music is persistently played in Colombia's mass media. Such prevalent contact has made a big part of our lives, and these high school students seem to find pleasure in listening to music in this foreign language.
The part of the study we report on here focuses on the identification and characterization of the factors that may influence students' participation when songs with social content are used in the EFL classroom within a framework of literacy as a situated social practice and using a critical view of pedagogy.

\section{Conceptual Framework}

\section{Literacy as a situated social practice: a room for participation}

This research has a social situated perspective on literacy since it goes beyond the focus on learners' individual acquisition and development of language skills such as writing, listening, speaking, and reading; the emphasis is rather on how people use language to reflect upon their everyday lives and their relations with the others and with the world, specifically with the context they live in.

Baynham (1995) defines literacy as a situated social practice as a set of characteristics that are present in daily activities: First, literacy practices have to be seen as a solid human activity which means construction of society from the perspective of a context and what people can do with it. Second, literacy events are seen as social and interactional because they are made in community. Third, a mediator of literacy is seen as a person who helps others to be literate using their skills. Fourth, networks have to be reciprocal exchanges allowing them to be literate within social relations. Fifth, domains of literacy are related to where people use literacy and how they use it. In short, it can be said that literacy as a situated social practice is the possibility that every person as an individual has in order to have exchanges with others and be an active participant in the society, taking into account the real context and social issues.

Literacy in this study goes beyond helping people learn how to read and write in the foreign language, it holds a social perspective in which individuals reflect upon real situations and construct ideas in order to become free (Freire \& Macedo, 1987). That is, students become literate about their histories, experiences, and the culture of their immedi- 
ate environments. This view of literacy is relevant to this study because it emphasizes on both the individual and social dimensions involved in the process of becoming literate. In the particular EFL classroom where this study takes place, we consider it is important to provide students with spaces and activities in which they have the opportunity to feel free to share their experiences, to find their voices, to be heard, to value each others' ideas, and to be critical of what is happening in their context and in the world. Implementing this type of approach to literacy in the EFL classroom has shown to provide students with the opportunity to reflect upon real issues and to get into a dialogic process of analysis of their own reality (see Chala \& Chapetón, 2013 and Chapetón \& Chala, 2013).

In this respect, we believe it is important to use authentic material as a resource to learn a foreign language. As Guevara \& Ordoñez (2012) pointed out, songs in English represent this authentic material that can be implemented in the EFL classroom. However, for learners to be able to explore the two dimensions of literacy, it is vital to use songs within a social-situated perspective, so that students can get involved in meaningful, critical and dialogical interaction that may foster active participation.

\section{Critical pedagogy: fostering empowerment and reflection}

Critical pedagogy is understood in this study as a view of pedagogy that encourages students to understand the importance of considering the classroom not only as an academic location to learn contents of the subjects but as a space to reflect upon the daily situations that they live and experience; this is achieved in order to recognize the significance of their ideas and the way they can contribute to the transformation of their own reality.

According to Giroux (2001) critical pedagogy opens a space in which students become critical agents who wonder, question, and discuss the relationship between theory and practice, based on criticism and on what they see around them, analyzing learning and social changes. The purpose of critical pedagogy is to allow students to be able to empower themselves to be critical of social situations; furthermore, pedagogy should provide the conditions for students to be able to create awareness regarding the project of building social equity from a critical perspective, taking into account that pedagogy represents a relation with the future as well as with the past and the present.

In agreement with Freire (1985), we, as critical educators, support the idea of providing students with the tools to be critical about their real life situation and education; he states that this way of living critically permits students to be aware of establishing connections between their individual problems and experiences and the social environment in which they are involved. In this way, they can take significant actions to live in a better society.

This concept is very important for this study for two main reasons. First, it may help students become open minded and conscious about what they can do in order to contribute with new ideas and possible actions to change situations in their immediate world. Second, the use of this kind of pedagogy should encourage and empower learners to contribute to the EFL class construction and development, and it might allow students to express their feelings and points of view in different ways.

\section{The use of songs in the EFL classroom}

In order to refer to the use of songs in the EFL classroom, it is necessary to talk first about the definition of text which enlightens our understanding of songs. Chapetón (2007) defines text saying that it goes far beyond the printed word: "a text is everything possible to be read and to be rewritten; our own realities and life experiences are texts we can read aloud and rewrite by being critical readers of them" (p. 30). This definition is very important here because songs are seen in this study as texts that can be read by every individual from their own perspectives having critical positions; here, a text is not only a sequence of paragraphs that represents an extended unit of speech. Text in this study refers to the contents of the songs which are social and can be read 
and interpreted by each individual, bringing to mind their real life and their own experiences, connecting those with the way in which social processes are being displayed in the songs.

The importance of songs in encouraging students to learn English and enhancing learner involvement is widely accredited by esl practitioners (e.g. Giudice, 1986; Reeve \& Williamson, 1987) and EFL researchers (Cuestas, 2006; Duarte, Tinjacá \& Carrero, 2008; Morales, 2008; and Perez, 2010). Teachers and students in a similar way find songs as a useful tool in teaching and learning because they entertain and relax, offering a change from the routine procedures in the classroom. They are very useful tools to build up language abilities, especially oral skills. Also, learning English through songs provides a different environment for students who are usually afraid when speaking the foreign language in a formal classroom setting.

Additional benefits of using songs in the EFL classroom that are key in this study refer to the opportunities songs offer for students' participation in their own learning processes. Choosing the material they want to use can increase their motivation to learn (Cuestas, 2006). Similarly, it was observed by Morales (2008) that students can maximize their participation using meaningful tasks through the use of authentic materials such as rock songs by expressing their opinions, feelings, and reactions.

\section{Methodology}

This was a qualitative study aiming to gather indepth understanding of human reactions and the reasons that produce that behavior (Johnson \& Christensen, 2004).We use a qualitative paradigm since it allows the researcher to "enter into the world of participants" (Corbin \& Strauss, 2008, p. 17) and gain understandings of how they experience events in particular contexts and through specific interactions. This study is also an action research that emphasizes on reflection upon pedagogical practice with the aim of identifying ways to improve it (Burns, 2010; Sagor, 2005, and Wallace, 2006).
This study looked deeply at a group of high school students at I.E.D. Fabio Lozano Simonelli in Bogotá, a public school located in Usme, at the south of the city. The participants of the study were 42 students who belonged to $11^{\text {th }}$ grade. Their ages ranged from 16 and 19 years old. All of them belong to the second social stratum and they live in the south of the city. In addition, none of them has taken any English course in other institutions due to economic factors; most of them belong to families with low economic resources in which the parents did not have access to education. Finally, it is important to mention that they live in a context in which there are many social problems related to violence, because of displacement, poverty, drugs, and gangs. The majority of these students spend most of their free time with their friends on the streets or they stay alone at home because their parents have to work all day long.

\section{Data collection sources and procedures}

The data were collected with the use of four instruments. First, two questionnaires were designed, piloted, and used: one, at the initial stage of the process to create a students' profile and to inquire about the participants' preferences and interests in relation to music. This was particularly useful to plan and design the pedagogical intervention. A final questionnaire was administered to explore the outcomes of the experience of using songs with a critical approach after the intervention had taken place. Second, field notes were used in every class session during ten weeks (two class sessions per week). They provided important information about students' interactions and participation in the classroom sessions. In order to gather students' opinions, perceptions, and feelings about the process that was being carried out, three semi-structured interviews were designed and used after the end of each cycle. Finally, students' productions (artifacts) were the result of the activities developed in each class session where a song was used. 


\section{Instructional design}

As Lewis (2001) points out, literacy practices are primarily socially situated acts. In this study, the use of songs, taken from this situated social perspective, was seen as a literacy-related social practice taking place in the EFL classroom where learning and participation were at the core. Learning, from this perspective, "involves engaging in a process whereby one progressively becomes a fuller and more valued participant in a specific social practice" (Lewis, 2001, p. XVII).

Framed within a literacy as a situated social practice perspective, songs with social content were used in the EFL classroom through activities organized in three cycles according to different aspects of the students' lives. First, there was a cycle related to the students' social context. It was called "My social environment". This refers to the immediate physical and social settings in which students live or in which something happens or develops. The songs used in this cycle were: Eagle Fly Free (Helloween), Gangsters' Paradise (Coolio), and Where is the Love (Black Eyed Peas). The purpose was to help students reflect about things happening around them by expressing their points of view and feelings with regards to society and how their literacies can contribute to think of a better world. The second cycle, named "Me and my relationships with others", wanted to make a reflection about how people interact in their communities and how each student's life can be influenced by these interactions. The implemented songs were: Welcome to my Life (Simple Plan), Family Portrait (Pink), and Another
Day in Paradise (Phil Collins). The third cycle analyzed the importance of each student caring and valuing him/herself recognizing their virtues and flaws. It was called "Myself". The songs used in this cycle were: It's my Life (Bon Jovi) and Freewill (Rush). The activities and workshops were designed to encourage reflection and participation with a critical approach and they included workshops and creative works such as paper craft (friso), a cartoon, and a model in clay. The pedagogical purpose was to provide spaces for students to share with their classmates, to freely express their feelings, thoughts and ideas about issues of their concern and discuss possible ways to transform those realities through dialogue. That is, to become active participants in the EFL classroom by using songs in English that could be meaningful to them.

The next section presents the outcomes of the study. It will show the original voices of the participants as they were actually produced during the EFL classroom sessions and recorded through the different data collection instruments.

\section{Findings}

After using the grounded approach, an inductive method for data analysis (Corbin \& Strauss, 2008), two core categories emerged in relation to the factors influencing students' participation in the EFL class, when songs with social content are used within a framework of literacy as a situated social practice. As shown in table 1, data revealed that factors were related to the songs on the one hand, and to the students themselves, on the other.

Table 1. Categories resulting from the analysis

The musical genre as an encouraging or discouraging factor.

Factors related to the songs

Factors related to the students
Songs' contents as factors that influence students' class participation and interaction.

Complexity of the songs in linguistic terms as a factor that may limit students' participation.

Students' stage of life as a factor that facilitates the development of the activities.

Previous life experiences as a factor that influences expression of the students' points of view.

Source: Authors. 
These categories refer to the factors that influence the way students participate in class, develop the activities proposed, show involvement and engagement, as well as enjoyment and pleasure when learning the foreign language in the classroom context within a framework of literacy as a socially situated practice.

\section{Factors related to songs}

\section{The musical genre as an encouraging or discouraging factor}

This refers to the likes and dislikes students have in terms of music genres and how this can influence their class participation being an encouraging or discouraging factor. Data suggests that students are able to do the activities with self-confidence depending on the musical genre used in the activities. Also, it showed that having enquired about students' likes and dislikes in relation to music through the use of the initial questionnaire was important for the participants in the development of the activities in this phase of the literacy as a situated social practice. Keeping their music preferences in mind was useful for obtaining methodological ideas and focusing more on the genre and rhythms of the songs that were used in the activities; besides, this kind of activities gave participants the opportunity to contribute to consolidate literacy as a social practice through participation, fostered by the use of songs in the classroom. The following excerpt illustrates this point:

S32: Fue importante tener en cuenta el tipo de música que nos gustaba o al menos algo similar porque en inglés es diferente, pero así se pudieron crear actividades basadas en nuestras preferencias y así concordar con las tendencias de nosotros y enriquecer las actividades y así se participó más activamente. (Third Interview, December 3)

As shown in the previous excerpt, having in mind students' musical interests and using them in the EFL class were important factors that enhanced their participation. The data analysis revealed that encouraging and discouraging factors depended both on the musical background students had and also on how the activities were implemented:
S38: que hay géneros que también son muy buenos y eran para gente joven y por eso me interesaron. (Second Interview, November 15)

S27: cuando me preguntaron yo dije que me gustaría rap, reggae y rock y escuchamos canciones de esas, menos reggae, pero igual todos los géneros me gustaron. (Third Interview, December 3)

S4 volunteered to participate in the contest; he is listening to the music and paying attention to the instructions. They seem to be active participants of the activity [the creation of the friso]. (Field notes, October 11)

Students seem to be interested in the activity because they were working hard in order to be ready to express what they feel and think about the song and the proposed activity. (Field notes, October 16)

The music genre plays a relevant role because music belongs to a shared tradition of students' personal and social background. It was seen that depending on the genre, students could take advantage of the activities using songs, which they found interesting and provided them with the opportunity to work in a comfortable way. Also, most of the activities of songs that belonged to their preferred genres seem to be highly encouraging. The data showed that most of the students were enthusiastic during the development of the activities and few of them were discouraged:

S33: me gustan las canciones románticas porque hablan de cosas que yo siento y no digo. (Final Q., December 5)

S15: el rock me encanta porque me hace reflexionar sobre temas de mi entorno social y así es más fácil realizar las actividades. (Field notes, November 13)

The previous samples show that the music genre was an encouraging factor that allowed students to feel identified with certain types of music in the EFL classroom. Music also encouraged them to express their feelings, find their voice, reflect about their 
personal and social realities, and facilitated involvement in the development of the activities.

However, it was also found that in some cases students felt discouraged for different reasons. Sometimes, the rhythm of a song was fast and they could not get the idea; in other cases, students disliked the genre; and in others, they had never listened to English music because they preferred other genres in their L1, Spanish. Also, the music genre is a factor that can affect the understanding of the song content and can also influence students' participation in the class sessions. The following excerpts illustrate these points:

[...] but students also say the rhythm and the lyrics of the song are fast. (Field notes, October 18)

S34: La canción del águila no me gustó porque era muy rápida y no alcancé a hacer todo el trabajo, y me tocó terminarlo en la casa. (Final Q., December 5)

S11: A mí no me gusta la música en inglés porque la mayoría no se entiende, además me gusta es el reggaetón. (First Interview, October 30)

S8: una canción que era un rap, intenté hacer la actividad y no me gustó por el ritmo y por eso la actividad me quedó fea. (Third Interview, December 3)

S27: la verdad a mí me gusta es el reggaetón y a la música en inglés nunca le puse atención, hasta ahora en la clase de inglés. (Third Interview, December 3)

Data thus reveals that the music genre used in the EFL classroom is a factor that can influence students' participation. When students' preferences are taken into consideration, they seem to be more engaged in the activities proposed. They seem to feel more comfortable and free to find ways to express their thoughts, feelings, and ideas. This fact points to the importance of considering student's voices in terms of the actual music genres they like so that they can be part of the class repertoire and foster active participation.

\section{Songs' contents as factors that influence students' class participation and interaction}

Songs' contents constitute another fundamental factor for the development of the activities because they promote interaction and discussion, and they also make students assume critical and constructive points of view about their reality. In this way, students become involved with a participative attitude, reduce their fears, and demonstrate their ability to take advantage of what they know about their environment, relating their real context with the songs, in order to be active agents in the society. Taking into account what students expressed, it can be said that their increasing interest in the class may be a result of the implemented activities and previous experiences in relation with the songs' topics. In the following excerpt, taken from one of the students' interview, it is mentioned that active participation in the EFL class sessions was related to the contents of the songs that were implemented in the activities:

S35: el uso de canciones en clase me parece interesante, enriquecedor y muy chévere permitiéndome participar porque no había tenido clases en que los temas sean interesantes y se toquen a través de la música. Eso me permitió expresar mis ideas, opiniones y ver el pensar de otras personas, autores y conocer canciones. (Third Interview, December 3)

This response shows how learners felt the content of the songs was interesting and a useful starting point for expressing their feelings, ideas, and opinions, sharing them in the EFL classroom context, and learning about others' thoughts and feelings. In addition, students considered that the main factor that contributed to their interest was the lyrics of the songs. The lyrics allowed students to be creative, to enjoy the class activities, and to find an opportunity to express their feelings and ideas making connections to the contents of the song. Here is an excerpt from an interview that illustrates this point:

S8: pues uno aprende vocabulario y entiende la canción pero principalmente el contenido de letras de la canción como forma de reflexión y pasatiempo, porque las actividades son buenas, 
porque permiten que cada persona exprese su forma de ver el mundo desde lo personal y convivencial (sic). (Second Interview, November 15)

The data showed that students participated in the activities interacting with their partners especially due to the contents of the songs. This was an important opportunity to express and share reactions and points of view, and to see the way they interpreted their reality in relation to songs with social content when literacy was considered as a situated social practice:

S8: Pues para mi vida participar es útil ya con las canciones aprendo cosas que de pronto no sé y antes no aprendía en Inglés y con ellas me doy de cuenta la relación de mi contexto y el mundo. Además yo estoy muy interesado ya que las canciones contienen temas muy interesantes y para nosotros como jóvenes que vamos a descubrir el mundo y una sociedad muy dura, pues eso decimos con S9, S2 y S3, (...) el esfuerzo es un poco más grande [en inglés] pero lo hago para ver que puedo aprender de la vida, de los demás como sufren... (First Interview, October 30).

The data above also shows that based on the topics discussed in the songs, students are able to participate actively in the social construction of reality and reflect upon issues that surround them. In doing so, students engaged in dialogic interactions that allowed them to express their personal opinions and become active participants in the EFL classroom. In addition, students expressed that they felt confident with activities that provided opportunities for dialogue. This was relevant and effective for them because it encouraged them to improve their social interaction and participation in class.

When students were asked about their class participation, they said that they had participated because the selected songs were interesting and connected to their preferences and realities. It was seen that they participated because they liked the topics using songs with social content. Thus, using songs with social content seemed to be something important because it fostered participation as shown in the following data samples:
S38: algunas veces me llamó la atención los temas y por eso participé harto (sic). (Third Interview, December 3)

Students seem to be happy because the topic of the song is something that can be related to them. (Field notes, October 23)

The data revealed that students liked to work with personal and social issues during learning, and it also showed that they liked using songs with social content because this kind of activities featured some problematic topics that had to do with real issues that affected them. Consequently, students showed interest in learning English through songs that dealt with social issues since some of the topics were related to their social environment. Examples of data that illustrate this issue are presented as follows:

S35: ...las canciones tenían unos temas muy interesantes que a veces uno escucha pero no les presta atención. (Final Q., December 5)

S11: las canciones reflejan algo de mí ya sea en la cultura o lo personal. (Third Interview, December 3)

S12: pues yo conozco esas temáticas pero a veces no me importaba porque afectaban a otros y no a mí pero ya he cambiado un poco esa forma de actuar. (Final Q., December 5)

S42: la verdad las canciones están muy relacionadas con la realidad que se vive por ejemplo, pandillas, la injusticia social, la guerra, los problemas de familia y otras cosas así que están relacionadas con nuestra realidad. (Final Q., December 5)

S42 es voluntario para exponer su actividad y comienza diciendo "el tema de la canción es social y nos hacen ver la realidad que estamos viviendo en nuestro país y en nuestro mundo, por ejemplo la violencia, las armas, las pandillas que es lo que a diario vivimos algunos en el barrio". (Field notes, October 23).

S12: el tema de la violencia es algo que nos afecta a todos porque no podemos hacernos los locos por ejemplo en mi barrio hay muchas pandillas que mantienen a la gente con temor $y$ a veces aparecen 
muertos debido a los problemas entre ellos, pero igual nadie hace nada y con esas familias que se mandan peor (sic). (Final Q., December 5)

As shown before, students participation in the EFL class sessions was fostered as they were able to relate the songs' contents to their own realities. They referred to social issues that are present in their daily lives such violence, gangs, family conflicts, etc. They were free to express how they feel about those issues assuming a critical position which seemed to be fostered by the use of songs with a social content framed within a situated social perspective towards literacy and using a critical view of pedagogy that foster these critical readings of the world.

\section{Complexity of the songs in linguistic terms as a factor that may limit students' participation}

Given that all human beings use language to communicate, to express ideas and feelings, and have connections with other people, songs with social content can be seen as a way to develop communicative skills in the English language; through songs, participants can develop communicative skills in English and discuss the social content related with their social environment. According to Giroux (1994), this can allow students to question, voice, power, and evaluate relationships; this means they can develop communicative skills permitting them to express what they think. The following excerpt illustrates how songs with social content are a way to encourage students' participation and initiative to start developing communicative skills in the English language:

S31: las canciones con ese tipo de contenido nos ayudan a dar nuestro punto de vista desde nuestra convivencia (...) aunque no sepamos inglés perfectamente, using Spanglish. (Final Q., December 5)

Students present their works with some grammatical mistakes but it is understood because of the creative work they have done and the way they try to express themselves. (Field notes, October 11)

In these data samples, it is possible to see that if students do not know completely the grammar of the foreign language, although it constitutes a limitation, it does not constitute a barrier that impedes students to communicate. Furthermore, the teacher's help is fundamental, because beyond error correction is the critical position students assume when expressing their ideas. Also, if they have support provided by the teacher and classmates on a dialogic basis, it can generate a successful communication where opinions, ideas, and feelings are successfully communicated. Although in EFL classroom sessions we can identify and correct formal mistakes, it was not the main purpose of the study; the purpose was to make them feel free to communicate and express themselves, to become active participants in the EFL class, taking a perspective of literacy as a situated social practice, through the use of songs with social content.

Given the fact that the participant students in this study were still in a process of learning a foreign language in a classroom context and they did not have solid bases, encouraging self-confidence was important. It allowed the development of social interactions, bringing real experiences to class through songs; in turn, this motivated the development of students' communicative skills in English but having their mother tongue as a resource.

I write in Spanish sometimes, because I do not understand some vocabulary. (Student artifact, November 27)

S33: el uso de canciones es importante y enriquecedor uno aprende buen vocabulario aunque al comienzo toca usar español e inglés porque uno no sabe mucho aunque la canción se pueda comprender... (Second Interview, November 30)

The activities implemented in the EFL classroom were useful not only to help students develop their communicative skills but also to encourage students to use literacy as a situated social practice through the use of songs; this means that students shared ideas using different strategies to convey the message they wanted to. Although some students' low proficiency in English was a limitation for them to communicate with peers, they were able to overcome this difficulty using the L1. Given the fact that 
communication was of the essence, students did not allow low proficiency or lack of vocabulary to interfere in their way of thinking and communicating their points of views, feelings, and beliefs:

S11: no pude escribir o hablar todo en inglés ya que ni mis compañeros ni yo tenemos el suficiente contacto con la lengua. Además yo soy un poco ¿bruta? para el inglés, pero a través de las actividades logré hacerme entender en spanglish. (Third Interview, December 3)

As shown in the previous excerpt, the lack of contact with (i. e. exposure to) the foreign language is identified by students as being part of the linguistic limitation they have to express themselves in the class. Other limitations may be related to the way they actually feel when using a language that is not (linguistically) familiar to them: Students expressed that they felt shy or embarrassed because they had to present their works in English, a foreign language they seem not to feel familiar with; and when they tried, it was somehow difficult to understand what they wanted to mean. They usually used their L1 as a resource to communicate and to show understanding of the songs' contents.

S38: a mí no me gusta participar porque me da pena además el inglés no se usa acá mucho. (First Interview, October 30)

La estudiante (S30) expresa vergüenza porque le da pena hablar en inglés entonces lo hace en español pero aclara que tiene clara la temática de la canción. (Field notes, November 6)

Furthermore, students considered that although their low proficiency in English was a barrier (added to the linguistic distance they perceive), it did not mean that they could not express what they thought. Not knowing how to communicate in the foreign language or the lack of vocabulary were seen as limitations that required extra efforts, however, the activities' purpose motivated them to overcome these difficulties. As Harmer (2007) argues, each learner constructs his/her own grammar depending on their learning process and according to the way they express what they know and feel about their real life situation. Data showed that students took advantage of the activities in order to communicate their ideas and feelings. The next excerpts support these claims:

S35: las actividades realizadas en clase me parecieron muy buenas aunque en ciertos momentos el no conocer mucho vocabulario me hacía demorar más en expresar y comprender algunas temáticas entonces me pareció que esto era un impedimento para realizar las actividades de forma más ágil. (Third Interview, December 3)

S8: Pues yo creo que no saber hablar inglés es una barrera para comunicar ciertas ideas pero más que hablar lo importante era hacerse comprender a través de las diferentes actividades didácticas. (Final Q., December 5).

Data demonstrates that the L1 is still a very important resource for students to communicate their ideas in the EFL classroom. It can facilitate interaction, encourage participation and, as stated by Pan and Pan (2010), it can reduce any insecurities that may arise from students limited proficiency in the foreign language. Data thus reveals that a perspective of literacy as a situated social practice provides opportunities for active participation, engagement and interaction that go beyond the grammatical or linguistic limitations learners of a foreign language may have.

\section{Factors related to students}

Students' stage of life as a factor that facilitates the development of the activities [T4] Understanding stages of life means being capable of identifying visible changes in individuals during life. This means the stages themselves are the change periods, the periods of most obvious physical and psychological change. This seemed to be a factor that influenced students in order to develop the proposed activities. Participants in this research were between 16 and 19 years old. This stage of life they are at, allows them to understand the issues in their community from the perspective of young people who are still in the process of getting to know and construct visions of life and of the world in a more serious and structured 
way. They acknowledged and brought into play their background, present experiences, and their role in the school community. This seemed to facilitate and encourage their participation in the class activities as shown in the following excerpts:

S21: los temas que tratamos eran acordes a lo que ya hemos vivido. (Third Interview, December 3)

S9: Las actividades fueron interesantes porque a nuestra edad se puede discutir acerca de la realidad social facilitando el desarrollo de las tareas. (Final Q., December 5)

S38: nosotros en algunas ocasiones somos inmaduros pero en este caso hemos trabajado chévere porque las actividades son con canciones con temas interesantes y ya en once hay que dar ejemplo. (Second Interview, November 15)

In these examples, we can see that the stage of life in which the participant students were, allowed them to make connections with their life experiences, discuss about their current realities, enjoy the development of class activities, and perceive themselves as active agents of their communities. Considering that the topics were appropriate to be handled and discussed by people at this stage (16 to 19 years of age), students' learning and teaching processes were favored through the development of the activities as proposed in the EFL sessions which were framed within a situated and social perspective to literacy where background, present experiences, and roles in the community are at the core (Baynham, 1995; Shor \& Freire, 1987).

\section{Previous life experiences as a factor that influences expression of the students' points of view}

Using songs with social content as a means for self-expression in this study was a way for students to express thoughts, feelings, and opinions in any way either speaking, writing, or something artistic that expressed what they felt. This idea also refers to the manner in which they interact with others and the way they interpret the world when they express themselves. As Baynham (1995) suggests, literacy is inside daily activities, this means every- thing students do is related with the things they live and know. These opinions and points of view reflect their previous life experiences which were expressed through their participation in the class sessions and through the creative artefacts students produced. We can see it in the next extract, which is related to what students consider as self-expression:

S9: el hecho de expresar lo que pienso teniendo en cuenta las canciones con contenido social es muy útil porque expreso cosas de la vida real que pienso, que he vivido, y me daba pena decir. Es muy fácil expresarse a través de las manualidades que hemos trabajado en clase y esto me permitió interactuar, compartir lo que había plasmado en mis trabajos además permitir que los demás los interpretaran. (Second Interview, November 15)

In this part of the interview, it can be evidenced that students expressed themselves through creative activities; in this respect, it is important to mention that these activities were not seen only as a product (Grundy, 1987) that was graded, but as an opportunity to allow them to feel comfortable expressing what they felt or they have experienced in their real life. The participant EFL learners also expressed that most students in their school tend to be afraid of expressing what they think or feel because of their partners' attitudes toward speaking in English; they expressed that they also experienced this with the development of the activities. However, it seemed that the activities developed in the classroom sessions facilitated the students' expression of their ideas since they provided a more comfortable and friendlier environment. The following extracts illustrate this claim:

S4: ...pensé que iba a ser más difícil expresar opiniones y reflexionar ya que da un poco de vergüenza pero con el uso de canciones da una idea de cómo se relacionan mis vivencias con la canción dándome así más confianza al expresarme con menos temor al error. (Second Interview, November 15)

He [S40] said he was happy. Students seem to be interested in the activity because they seem to enjoy working hard for expressing what they feel and think about the proposed activity. (Field notes, November 8) 
Through socialisation and personal reflection, the participants of the study became aware that they needed to fulfil a purpose. It was demonstrated by the data that previous life experiences were vital because they brought them to each activity. Bearing in mind what students expressed, it seems that their sharing attitude was a consequence of the activities that were implemented and their connections to previous experiences in relation with songs' topics. Based on the data, it is evident that students become willing to share and express their opinions about what is happening in their real context, a fact that also facilitated their participation in class.

S22: la canción de las pandillas me recordó lo que pasa a diario en mi barrio por eso fue fácil de resolver el taller. (Final Q., December 5)

S8: Pues para mi vida participar es útil ya con las canciones aprendo cosas que de pronto no sé y antes no aprendía en Inglés y con ellas me doy de cuenta la relación de mi contexto y el mundo. (First Interview, October 30).

S19: pude expresar mis opiniones personales y así desarrollar más fácil las actividades. (Second Interview, November 15)

The development of the activities in class had a connection to the students' background, which had an impact in the way they expressed their points of view since they were able to link the content of the songs and the topics with their own context where similar situations took place. Expressing points of view in the EFL classroom through the work with songs with social content implied thinking about previous life experiences which might help students to state their points of view based on what they really knew as members of a community. Based on the analysis of the data it is possible to state that many of the participants considered that working with songs helped them to establish links with their own lives and contexts:

S14: para mi es interesante porque en cada experiencia de la vida se esconden sentimientos de desesperación, amor, intriga que queremos expresar como sea a la sociedad y por medio de las canciones se pueden expresar puntos de vista teniendo en cuenta lo que hemos vivido y nuestra cultura. (Third Interview, December 3)

S41: el trabajo con canciones me permitió expresar lo que creo y siento de las cosas que se viven a diario en mi casa y el barrio y aprender a ser mejor persona. (Final Q., December 5)

S23: algunas de las canciones me traen recuerdos de historias que conozco o cosas que he vivido y me permite compartir la experiencia con mis compañeros. (Second Interview, November 15)

Data shows that using songs with social content framed within a perspective of literacy that is social and situated can bring important opportunities for EFL learners to participate in class sessions by expressing their feelings, sharing opinions with classmates, retelling their life stories, listening to other's experiences, constructing realities and, as illustrated by the excerpts above, thinking of possibilities to be a better person willing to share experiences and voices with classmates.

\section{Conclusions and implications}

This qualitative action research has explored the factors that influence students' participation in the EFL classroom when songs with social content are used taking a social-situated perspective on literacy and a critical view of pedagogy. The findings obtained from students' voices and classroom observation show that this innovative way to use songs in this particular context (public high school) can encourage students to be reflective and active participants who find, construct, and share meaningful experiences and social realities in the foreign language classroom. That is, using songs in the EFL classroom can go beyond the fact of learning grammatical structures, vocabulary, and showing comprehension of the lyrics. When focusing on a social content that is of interest to students, it can foster reflection and expression of personal feelings and social concerns.

Findings indicate that factors related to songs and factors related to students can influence learners' participation in the EFL class. With regards to 
factors related to songs, the musical genre was found to be either an encouraging or a discouraging factor depending on students' musical background. The study showed the importance of considering students' likes and dislikes in terms of music genres. Their opinions not only contributed to the songs' selection but encouraged students' participation as they realized their voices had been taken into account for class planning and development.

Also, it was found that the songs' content influenced students' class participation and interaction because the lyrics of the songs were related to their real life and social environment. As the study advanced, they realized that the topics discussed in the songs were meaningful to them and links were made to their own realities. This facilitated and encouraged their involvement and interaction during the class sessions as they could share feelings, ideas, experiences, and ways to see the world. However, the linguistic complexity of the songs was a factor that may limit students' participation. This finding points to the fact that students' participation depends on their understanding of the content of the songs. At the beginning of the study, students were afraid to use English but they showed they can overcome the difficulties and realize this was not an impediment to communicate their ideas. Importantly, their L1 was a resource that helped them overcome those difficulties facilitating communication, involvement, and interaction.

The second factor influencing participation was related to the students themselves. Firstly, students' current stage of life facilitated their participation in the EFL class. They not only enjoyed the development of class activities but also, they perceived themselves as active agents of their communities. Secondly, students' previous life experiences were brought into play and influenced the expression of their points of view. Songs allowed learners to share life experiences, make individual and social readings of the world, and identify common realities.

In this study, the students were able to discover different dimensions of literacy. They were not interested only in grammatical issues and vocabulary learning, but also in the content of the songs and in the activities developed which were social-situated practices that allowed them to become interested in participating in the EFL classroom sessions. In addition, the activities developed became a meaningful experience for students because they were able to interact and reflect upon real issues and take hold of their experiences in order to use what they knew about the world.

\section{References}

Baynham, M. (1995). Literacy Practices: Investigating Literacy in Social Contexts. New York: Longman.

Burns, A. (2010). Doing Action Research in English Language Teaching: A Guide for Practitioners. New York: Routledge.

Chala, P. A., \& Chapetón, C. M. (2013).The Role of GenreBased Activities in the Writing of Argumentative Essays in EFL. Profile, 15(2), 127-147.

Chapetón, C. M. (2007). Literacy as a Resource to Build Resiliency. Bogotá: Fondo Editorial Universidad Pedagógica Nacional.

Chapetón, C. M., \& Chala, P. A. (2013). Undertaking the Act of Writing as a Situated Social Practice: Going beyond the Linguistic and the Textual. CALJ, 15(1), 25-42.

Corbin, J., \& Strauss, A. (2008). Basics of Qualitative Research: Techniques and procedures for developing grounded theory. Thousand Oaks: Sage Publications.

Cuestas, M. (2006). Songs in the English Class: A strategy to Encourage Tenth Graders' Oral production. Profile, 7(1), 47-57.

Duarte, M., Tinjacá, L., \& Carrero, M. (2008). Using songs to encourage sixth graders to develop English speaking skills. Profile, 14(1), 11-28

Freire, P. (1985). The politics of education: culture, power, and liberation. South Hadley, MA: Bergin \& Garvey.

Freire, P., \& Macedo, D. (1987). Literacy: Reading the word and the world. Westport, CT: Bergin \& Garvey.

Giroux, H. (1994). Disturbing pleasures: learning popular culture. New York: Routledge.

Giroux, H. (2001). Theory and Resistance in Education: towards a pedagogy for the opposition. Westport: Greenwood Publishing Group. Inc. 
Universidad Pedagógica Nacional

Facultad de Humanidades

Giudice, G. D. (1986). How to exploit a song in class (We are the world). Modern English Teacher, 14(4), 33-36.

Grundy, S. (1987). Curriculum: Product or Praxis? London: Falmer Press.

Guevara, D. C., \& Ordoñez, C. L. (2012). Teaching English to very young learners through authentic communicative performances. CALJ, 14(2), 9-23.

Harmer, J. (2007). The Practice of English Language Teaching. Essex: Longman.

Johnson, B., \& Christensen, L. (2004). Educational Research. Quantitative, Qualitative, and Mixed Approaches. Boston: Pearson.

Lewis, C. (2001). Literary Practices as Social Acts. Power, status and cultural norms in the classroom. New Jersey/London: Lawrence Erlbaum Associates Publishers.

Ministerio de Educación Nacional (MEN) (2006). Formar en lenguas extranjeras: Inglés jel reto! Estándares básicos de competencias en lenguas extranjeras: Inglés. Bogotá: Imprenta Nacional.

Morales, N. C. (2008). Using Rock music as a Teaching - learning Tool. Profile, 9(1), 163-180.

Pan, Yi-chun., \& Pan, Yi-ching. (2010).The Use of L1 in the Foreign Language Classroom. CALJ, 12(2), 87-96.

Perez, D. (2010). The role of music in young learners' oral production in English. Profile, 12(1), 141-157.

Reeve, C., \&Williamson, J. (1987). Look what you've done to my song. Modern English Teacher, 15(4), 83-85

Sagor, R. (2005). The Action Research Guidebook: A Four-Step Process for Educators and School Teams. Thousand Oaks, CA: Corwin Press.

Shor, I., \& Freire, P. (1987). A Pedagogy for Liberation: Dialogues on Transforming Education. Westport: Greenwood Publishing Group. Inc.

Wallace, M. (2006). Action Research for Language Teachers. Cambridge: Cambridge University Press. 